\title{
ANALISIS POTENSI DESA BERBASIS INDEKS PEMBANGUNAN DESA DI WILAYAH PESISIR KABUPATEN GRESIK
}

\author{
Roziana Ainul Hidayati \\ Universitas Muhammadiyah Gresik \\ roziana@umg.ac.id
}

\begin{abstract}
Progress is backward and there are still many MDGs indicators for Gresik Regency that have not reached the target, one of the reasons is the lack of available services and facilities, especially in rural areas located on the coast. One of the first efforts that can be done is to recognize the potential and problems of the local village community, so that they know the minimum services needed. This study tries to explore the problems and potentials that exist in villages in the coastal area by using the method of calculating the Village Development Index (IPD), where village officials are the informants and questionnaires are the data collection techniques. The type of study used is descriptive quantitative. Based on the results of the IPD study in the coastal area of Gresik Regency, precisely in Ujungpangkah District and Panceng District, it is known that the Developing Village Category in Ujung Pangkah District. The average variable that is lagging behind in almost all villages in Ujung Pangkah Subdistrict is the variable for Sports Facilities and Transportation Facilities. While the variables that are very good on average in all villages in Ujung Pangkah District are energy infrastructure, public health and the quality of human resources.
\end{abstract}

Keywords: IPD, Village Potential, MDGs

Corresponding author:

Email Address : roziana@umg.ac.id (Gresik, Jawa Timur)

Received 5 Januari 2021, Accepted 10 Pebruari 2021, Published 22 Pebruari 2021

\section{PENDAHULUAN}

Kabupaten Gresik sendiri jika dilihat berdasar capaian MDGs-nya tahun 2014, masih ada $53,13 \%$ indicator yang belum tercapai, artinya masih jauh dari harapan. Meskipun jika dibandingkan dengan tahun 2013 ada penurunan $1,87 \%$, tetapi indicator yang jauh dari target naik $3,02 \%$. (Gambar 2). Sementara Berdasar data dari BPS jawa Timur, Tingkat Kemiskinan Kabupaten Gresik Tahun 2017 mencapai 12,8\%. Angka tersebut menduduki urutan ke 14 dari 38 Kabupaten/Kota di Jawa Timur, artinya angka kemiskinan di Kabupaten Gresik masih cukup tinggi (Gambar 3).

Khusus daerah Pesisir di Kabupaten Gresik tepatnya di Kecamatan Ujung Pangkah dan Kecamatan Panceng, tingkat kemiskinannya berdasarkan hasil olah data capaian MDGs masih cukup tinggi yakni untuk Kecamatan Ujung Pangkah 22,52 \% dan Kecamatan Panceng 15.59 $\%$ (hidayati,2016). Berdasar hasil kajian yang dilakukan oleh Hidayati dan Sholichah (2010), penyebab kemiskinan nelayan yang tinggal di daerah pesisir Kabupaten Gresik adalah Rendahnya Law Inforcement dan Overfishing.

Fakta-fakta tersebut merupakan indikasi bahwa pembangunan di Kabupaten Gresik masih perlu upaya besar untuk ditingkatkan. Progress mundur dan masih banyaknya indikator MDGs yang belum mencapai target salah satu sebabnya adalah kurang maksimalnya kinerja layanan yang diberikan di Kabupaten Gresik. Salah satu upaya pertama yang bisa dilakukan adalah mengenal potensi dan permasalahan masyarakat desa setempat, sehingga mengetahui bentuk layanan minimum yang dibutuhkan. Hal tersebut selaras dengan hasil survey kepuasan masyarakat Kabupaten Gresik di mana tingkat kompetensi layanan masih perlu ditingkatkan khususnya terkait dengan kompetensi pelaksananya (Dinas Penanaman Modal dan PTSP; 2017) 



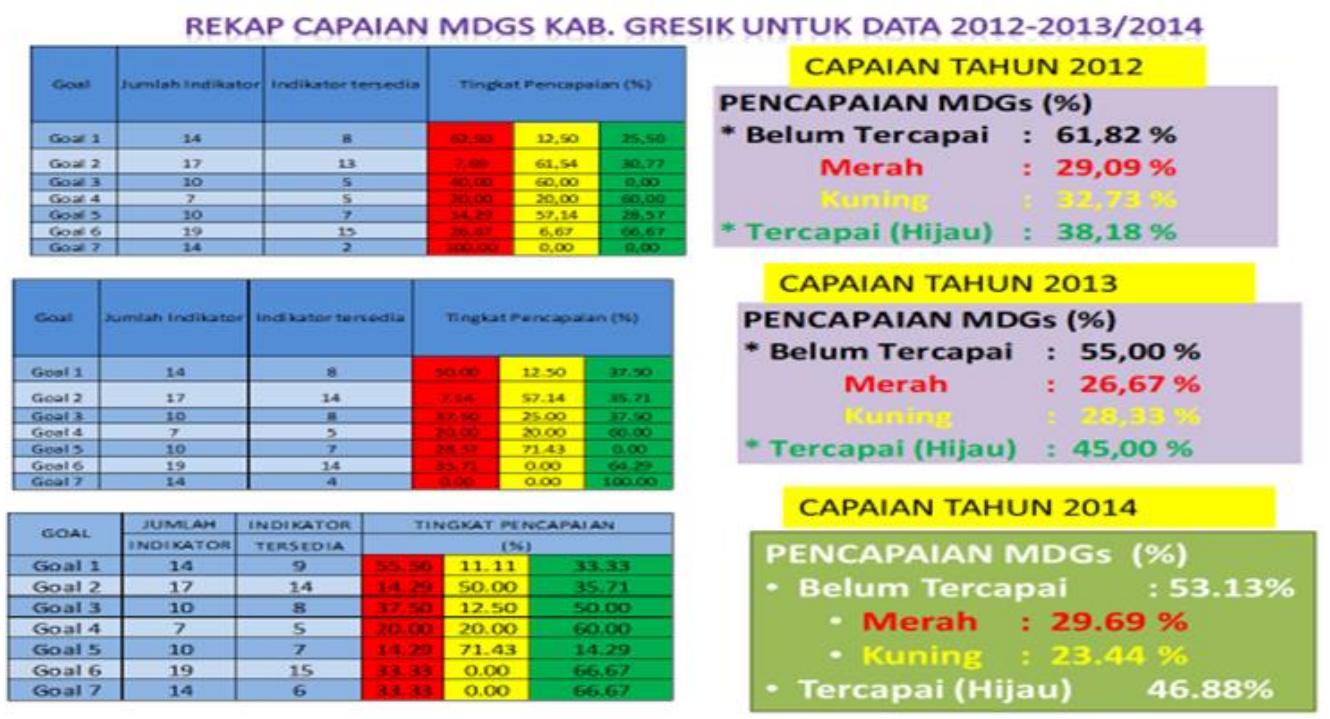

Gambar 2. Capaian MDGs Kab.Gresik

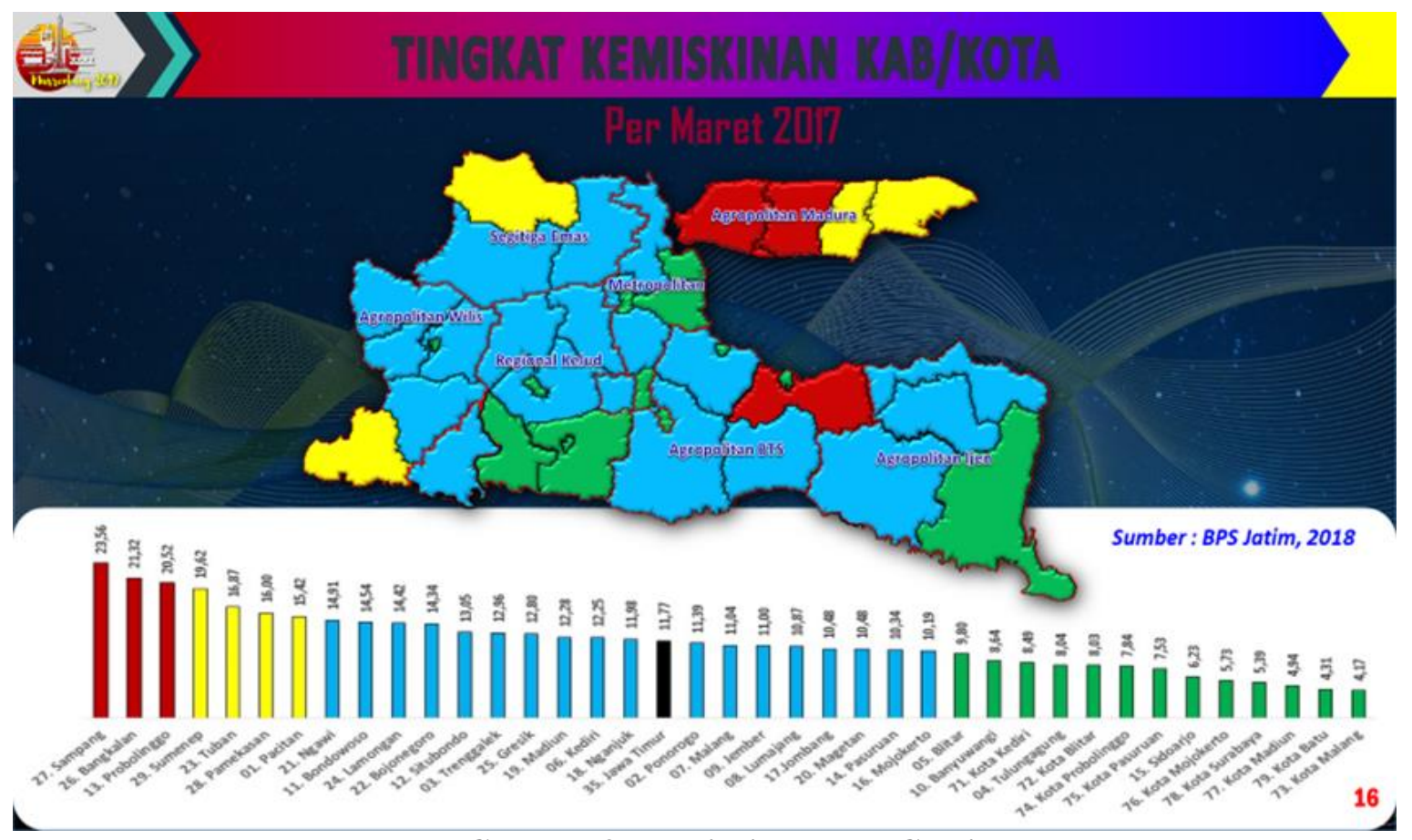

Gambar 3. Kemiskinan Kab.Gresik

Selama ini program-program yang di lakukan dalam rangka untuk menekan angka kemiskinan lebih banyak berupa charity, pembangunan fisik yang dirasa kurang tepat sasaran. Di samping itu banyak sekali kegiatan yang hanya bersifat duplikasi dari kegiatan tahun sebelumnya atau duplikasi daerah lain dengan maksud agar anggaran yang sudah dipagukan bisa teralokasikan. Ketidaktepatan program, kegiatan, sasaran, anggaran dan lokasi menjadi masalah serius dalam upaya penanggulangan kemiskinan desa. Setiap desa memiliki permasalahan kemiskinan yang berbeda sehingga tidak seharusnya program, kegiatan dan sasaran penanggulangan kemiskinan sama. Oleh karena itu perlu dilakukan kajian yang bertujuan untuk mengidentifikasi dan menganalisis potensi dan permasalahan desa pesisir di Kabupaten Gresik berdasar data Indeks Pembangunan Desa serta mengelompokkan tipologi desa pesisir di Kabupaten Gresik berdasar capaian indeks Pembangunan Desa. Urgensi dari kajian ini adalah sebagai bahan masukan bagi Badan Perencanaan Pembangunan Daerah (Bappeda) Kabupaten 
Gresik tentang potensi dan permasalahan desa pesisir di Kabupaten Gresik berdasar data Indeks Pembangunan Desa (IPD) serta sebagai masukan bagi Badan Perencanaan Pembangunan Daerah Kabupaten Gresik dalam Musrenbang saat menyusun Rencana Pembangunan Desa khususnya Desa Pesisir Kabupaten Gresik agar implementasinya efisien dan efektif. Selain itu juga dijadikan dasar acuan untuk menyusun model kegiatan pemberdayaan masyarakat desa di desa pesisir Kabupaten Gresik.

\section{TINJAUAN PUSTAKA}

IPD merupakan suatu ukuran yang disusun untuk menilai tingkat kemajuan atau perkembangan desa di Indonesia dengan unit analisisnya "Desa". Output dari penyusunan IPD ini adalah terpetakannya Desa-Desa berdasarkan tingkat perkembangan desa menurut IPD ke dalam 3 (tiga) klasifikasi yaitu: Desa Mandiri, Desa Berkembang, dan Desa Tertinggal di seluruh provinsi di Indonesia disertai dengan informasi untuk masing-masing dimensi, variabel, dan indikator penyusunnya. Dimensi dan variabel IPD didasarkan atas sintesa terhadap: (1) Data Potensi Desa (2) Undang-Undang Nomor 6 Tahun 2014 tentang Desa, khususnya pada pasal 74 tentang kebutuhan pembangunan desa dan pasal 78 tentang tujuan pembangunan desa. Dalam pasal 74 disebutkan bahwa paling tidak ada 4 aspek yang perlu dipenuhi dalam pembangunan desa yakni: (1) kebutuhan dasar; (2) pelayanan dasar; (3) lingkungan; dan (4) kegiatan pemberdayaan masyarakat Desa.

Hasil sintesis tersebut membagi dimensi IPD menjadi 5 dimensi yaitu sebagai berikut.

1. Pelayanan Dasar mewakili aspek pelayanan dasar untuk mewujudkan bagian dari kebutuhan dasar, khusus untuk pendidikan dan kesehatan. Variabel yang termasuk sebagai komponen penyusunnya meliputi ketersediaan dan akses terhadap fasilitas pendidikan serta ketersediaan dan akses terhadap fasilitas kesehatan.

2. Kondisi Infrastruktur mewakili Kebutuhan Dasar; Sarana; Prasarana; Pengembangan Ekonomi Lokal dan Pemanfaatan Sumber daya Alam secara Berkelanjutan.Variabel variabel penyusunnya mencakup ketersediaan infrastruktur ekonomi, ketersediaan infrastruktur energy, ketersediaan infrastruktur air bersih dan sanitasi serta ketersediaan dan kualitas infrastruktur komunikasi dan informasi.
3. Aksesibilitas/Transportasi dipisahkan sebagai dimensi tersendiri dalam indikator pembangunan desa dengan pertimbangan sarana dan prasarana transportasi memiliki kekhususan dan prioritas pembangunan desa sebagai penghubung kegiatan sosial ekonomi dalam desa. Variabel - variabel penyusunnya meliputi ketersediaan dan akses terhadap sarana transportasi dan aksesibilitas transportasi. Indikator jarak antara desa dengan pusat pemerintahan ini merujuk dari variabel yang tercantum dalam Potensi Desa, dengan asumsi bahwa pada umumnya pusat kegiatan sosial-ekonomi suatu kawasan berada di sekitar/ dekat pusat - pusat pemerintahan.

4. Pelayanan Umum merupakan upaya pemenuhan kebutuhan pelayanan atas barang, jasa, dan / atau pelayanan administrative dengan tujuan memperkuat demokrasi, kohesi sosial, perlindungan lingkungan, dan sebagainya. Karena kekhususannya, variabel pelayanan administratif dinyatakan sebagai dimensi tersendiri (Penyelenggaraan Pemerintahan). Pelayanan dalam dimensi ini mewakili aspek lingkungan dan aspek pemberdayaan masyarakat serta mengacu pada ketersediaan data Potensi Desa. Aspek lingkungan dalam hal ini terkait dengan kesehatan lingkungan masyarakat, sedangkan aspek pemberdayaan masyarakat diwakili dengan keberadaan kelompok kegiatan masyarakat. Oleh karena itu, variabel-variabel penyusun dimensi ini mencakup penanganan kesehatan masyarakat dan penanganan gizi buruk; serta ketersediaan fasilitas olah raga

5. Penyelenggaraan Pemerintahan mewakili indikasi kinerja pemerintahan desa merupakan bentuk pelayanan administratif yang diselenggarakan penyelenggara pelayanan bagi warga yang dalam hal ini adalah Pemerintah. Oleh karena itu variabel ini perlu diukur dan berdiri sendiri sebagai sebuah indikator pembangunan desa, karena sifatnya sebagai perangkat terlaksananya tujuan pembangunan desa tersebut. Variabelvariabel penyusunnya meliputi kemandirian dan asset/kekayaan desa serta kualitas sumber daya manusia

IPD disusun untuk menunjukkan tingkat perkembangan pembangunan di suatu desa. Nilai indeks mempunyai rentang $0 \mathrm{~s} / \mathrm{d} 100$. Untuk memudahkan interpretasi, dilakukan pengelompokan desa menjadi 3 kategori 
yaitu desa mandiri, desa berkembang, dan desa tertinggal.

a. Desa Mandiri adalah desa yang mempunyai ketersediaan dan akses terhadap pelayanan dasar yang mencukupi, infrastruktur yang memadai, aksesibilitas/transportasi yang tidak sulit, pelayanan umum yang bagus, serta penyelenggaraan pemerintahan yang sudah sangat baik. Secara teknis, desa mandiri merupakan desa dengan nilai IPD lebih dari 75.

b. Desa Berkembang yaitu desa mempunyai ketersediaan dan akses terhadap pelayanan dasar, infrastruktur, aksesibilitas/ transportasi, pelayanan umum, dan penyelenggaraan pemerintahan yang cukup memadai. Secara teknis, desa berkembang merupakan desa yang memiliki nilai IPD lebih dari 50 namun kurang dari atau sama dengan 75 .

c. Desa Tertinggal yaitu desa mempunyai ketersediaan dan akses terhadap pelayanan dasar, infrastruktur, aksesibilitas/transp ortasi, pelayanan umum , dan penyelenggaraan pemerintahan yang masih minim. Secara teknis, desa tertinggal merupakan desa yang memiliki nilai IPD kurang dari atau sama dengan 50 .

\section{METODE PENELITIAN}

Jenis kajian yang akan digunakan dalam kajian ini adalah deskriptif dengan pendekatan kuatitatif. Adapun jenis data yang digunakan dalam kajian ini adalah data primer, yaitu data yang diperoleh peneliti dari responden berupa data Indikator Potensi Desa yang berjumlah 42 indikator. Sedangkan Teknik Pengumpulan data primer ini adalah kuesioner.

Kuesioner di gunakan untuk mendapatkan data indicator potensi desa yang nantinya akan diolah untuk mendapatkan nilai indeks pembangunan desa berdasar indicator, variable dan dimensi sehingga akan dapat menghasilkan kategori (typology) desa. Populasi kajian ini Desadesa yang ada di Kecamatan Ujung Pangkah dan Kecamatan Panceng sebagai bagian dari daerah pesisir di Kabupaten Gresik, sedangkan respondennya adalah aparat desa sebagai pengisi kuesioner yang diambil dengan system purposive sampling. Adapun karakteristik aparat desa yang adalah yang mengetahui dan memahami potensi desa dengan baik. Dalam menganalisis data pada kajian ini digunakan teknik analisis sebagai berikut :

a. Teknik Penghitungan IPD

Penghitungan nilai Indeks Pembangunan Desa akan dilakukan dengan system manual excel dan akan dihitung nilai IPD setiap indicator, setiap variable, setiap Dimensi dan IPD setiap desa.

b. IPD Scorecard untuk menganalisis pencapaian IPD tingkat desa. Kartu ini disimbolkan dalam tiga warna, yaitu:

- Warna merah menunjukkan indikasi indicator/variable/dimensi/desa tertinggal.

- Warna kuning menunjukkan indikasi indicator/variable/dimensi/desa sedang berkembang.

- Warna hijau menunjukkan indikasi indicator/variable/dimensi/desa mandiri atau maju.

\section{HASIL}

Responden yang melakukan pengisian kuesioner data potensi desa adalah apparat desa di Kecamatan Ujung Pangkah dan Kecamatan Panceng. Desa di Kecamatan Ujung Pangkah terdiri dari 13 desa dan yang mengisi kuesioner Data Potensi Desa ada 13 aparat desa. Adapun 13 desa tersebut yaitu Pangkah Kulon, Pangkah Wetan, Sekapuk, Bolo, Banyuurip, Gosari, Cangaan, Karang rejo, Tanjangawan, Glatik, Ketapanglor, Ngemboh, Kebon Agung. Sedangkan Responden di Kecamatan Panceng dari 14 desa hanya 7 desa yang mengisi kuesioner.

\section{Capaian Variabel IPD Kecamatan Ujung Pangkah}

Berdasar Tabel 1. menunjukkan bahwa tidak ada satupun desa di Kecamatan Ujung Pangkah yang seluruh variable potensi desanya tidak ada warna merahnya (tertinggal), sedangkan desa yang sedikit variabelnya merah kurang dari 3 adalah Desa Sekapuk, Desa Gosari dan Desa Banyu Urip. Sedangkan desa yang variabelnya masih cukup banyak merahnya (tertinggal) adalah Desa Glatik dan Desa Ngemboh. Dimana Kedua Desa tersebut sama sama memiliki variable tertinggal pada variable Pelayanan Kesehatan, Sarana Transportasi, olah raga dan kemandirian. 
Tabel 1. Capaian Variabel IPD Kecamatan Ujung Pangkah

\begin{tabular}{|c|c|c|c|c|c|c|c|c|c|c|c|c|c|}
\hline WARAB. & 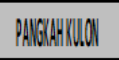 & YEOWAOUIT & Sglov & BHOUPP & NOD & 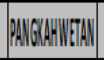 & OSSRAR & CAIGANI & IARAVETCO & THGGAGQWANA & Q64T & VFPANAGOR & NEENOWN \\
\hline 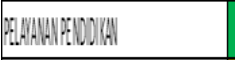 & VAOPR & Bretelantio & WHAP & BREABAlo & WADP & WADQ2 & NANPN & NAWN & IRTN $\mid 6002$ & Baxt13416 & WADR & VADO? & VADP \\
\hline 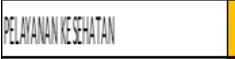 & Brovelballo & 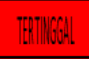 & Breclbatilo & 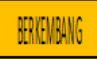 & Exellang & 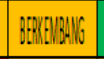 & VIAD2: & NADP & IRT) $\mid / 602$ & BRECBAy & BRECHWH & WAOPR & 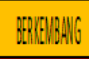 \\
\hline 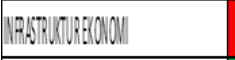 & 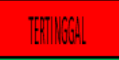 & IPThlow. & WAPOA & 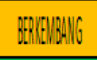 & 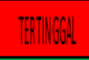 & Barelaly & Bexelay & IERTICON. & 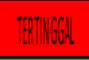 & $\mathbb{B R T} \| 60 \mathrm{~L}$ & 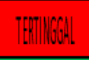 & IRT) & $\|\mathrm{BX}\| 60 \mathrm{~N}$ \\
\hline 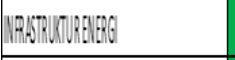 & NHOR & 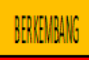 & WAOPY & WAOV? & NAWN: & WAPQP & WHWN & NAWR & WANP & WHWN & NHWN & WHOP & WAWP \\
\hline 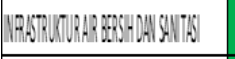 & WHOR & 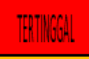 & WANA & VANOP & NANP & WADP & NADN & WHOR & NANDP & Whan: & WHOR & WADN & IADP \\
\hline 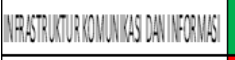 & WAON & BDECWWHO & Breclatilo & 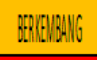 & 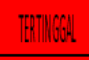 & WHAPR & BDECHWHOH & 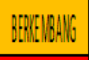 & WHON? & BREABANG & 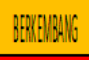 & WAWR & IHOP \\
\hline 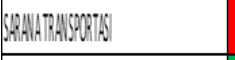 & Frillobit & BDECWWH & WANPV & TR716062. & TRP $1 / 1602$ & 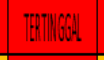 & TRP $1 / 1602$ & 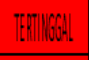 & BDECHAWG & 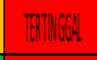 & 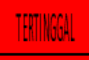 & TRTillGow & TRN\|GOL. \\
\hline 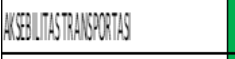 & WHOR & WHOR & WANOP & ERPEWHA & 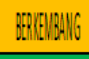 & 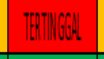 & BDECHWH & TRT) $\mid 600$. & WANOP: & 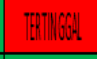 & IFT) 1602. & 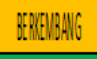 & TEX $\mid 1602$. \\
\hline 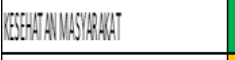 & VAOOR & IHOR & WAMPI & WADP & NADP: & WADPI & IENOP & WHWR & WHAP? & WANOP: & NAVR & WADOP & WAVP \\
\hline ownerat & 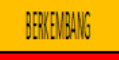 & BDEREAWG & Fin:G64. & TRTill6ot & TRP $1 / 602$ & Fin & TRP $1 / 1602$ & IER/ $\mid$ GOS. & 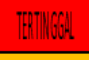 & 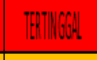 & 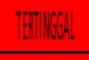 & TRT) & TEX $\mid 160 \%$ \\
\hline GuWPBAI & 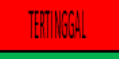 & 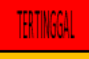 & BDECBA & Explay & Exellallo & 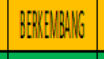 & Barelallo & 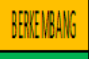 & WREGHWH & 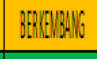 & IFT) $\mid 60 \%$ & 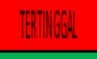 & 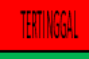 \\
\hline (WATISSON & VHOP & BDFEHANG & NADVN & WAON: & WADBA & WAPN & WHWN & WHWR & WANP & NAMP & WAOR & WHWOP & WADPR \\
\hline
\end{tabular}

Rata-rata kondisi jalan dan lalu lintas di desa tersebut memang sudah cukup baik akan tetapi ukuran jalan tidak lebar. Sedangkan angkutan umum juga masih terbatas di waktu tertentu. Fasilitas olah raga juga hampir bisa dikatakan terbatas, hanya sebatas memanfaatkan lahan kosong yang ada.

Selain beberapa ketertinggalan variable potensi desa seperti tersebut di atas, desa-desa di Kecamatan Panceng memiliki potensi desa yang sangat potensial yaitu kualitas sumber daya manusianya, penanganan Kesehatan pada masyarakatnya, serta infrastruktur energinya.
Meskipun Kecamatan ini berada di Ujung barat Kabupaten Gresik kondisi infrastruktur energi seperti penerangan jalan dan bahan bakar memasak cukup bagus ketersediaannya. Penanganan kejadian luar biasa (KLB), Penanganan gizi buruk di Kecamatan Ujung Pangkah cukup bagus selama ini. Kesigapan layanan di bidang Kesehatan masyarakat di seluruh desa di Kecamatan UJungpangkah berwarna hijau semua yang artinya sangat baik.

\section{Capaian Dimensi Indeks Pembangunan Desa Kecamatan Ujung Pangkah.}

Tabel 2. Capaian Dimensi IPD Kecamatan UjungPangkah

\begin{tabular}{|c|c|c|c|c|c|c|c|c|c|c|c|c|c|}
\hline DMESSI & PAGGEHAUDON & KBDONAWIIG & SELPPUK & BAWUVRP & BOOO & PAGGHWEWAN & GOSAR & CAOGAHAN & KAPANGESODO & IANAAGGWANA & GATK & NERPAGGOR & NGEMBOH \\
\hline PEEANAWANDSARP & WADRR & TEPTWGOH. & WADRR & BPREDEANG & BEREDEAAG & 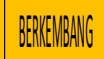 & NANDR & WADOR & IRTT WGOH. & BEREEBABNG & BPRECHANG & WANDR & BERENEBANG \\
\hline 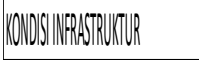 & WANRR & TEPTHWGA. & MANDR & BEREDEAHG & BEREEWAHG & BEPEEBBAFG & BEREDBANG & BEREEWANG & BEPEEBANG & BPENEWBANG & BPECEBAWG & BPECEBAHG & WANDR \\
\hline 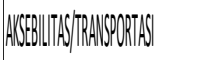 & BPEREABAG & BPRECBAWIG & WADOR & TRTA NGOA. & BEREEBANG & TERTIGON. & BEREDBAHG & TRET|VGOL. & BPEEWBANG & ETINGSW. & TEPTWGOH. & BPREBWANG & TRTA IGOAL. \\
\hline PEEAANAWUWWUN & BPEEBABAC & 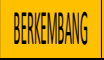 & BERENEBANG & BEREEBAWG & TRRT IGOAL. & BEREVEBAWG & BEREEBAHIG & TRPTIICOSL. & BEREEBANG & GoH. & BPECHEAWG & TRPTIGOHL & BERENEBANG \\
\hline 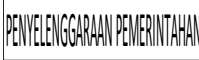 & BPREBPANG & BPECEBAHG & WANDR & WADNR & WANDR & WANDR & WHOR & WADAR & WANDR & WHOR & BPECEBAWG & BPECEBAHOHO & BERENEBANG \\
\hline
\end{tabular}

Tabel 2. menjelaskan bahwa di seluruh desa di Kecapatan Ujung Pangkah penyelenggaraan pemerintahan di desa-desa tersebut sudah cukup baik hal tersebut ditunjukkan dengan tidak adanya warna merah bahkan beberapa desa sudah mandiri dalam penyelenggaraan pemerintahannya yaitu Desa Sekapuk, Desa Banyuurip, Desa Bolo, Desa Pangkahwetan, Desa Gosari, Desa Cangaan, Desa Karangrejo dan Desa Tanjang Awan.
Dimensi yang harus menjadi perhatian serius dari desa - desa di Kecamatan Ujungpangkah adalah dimensi aksebilitas transportasi, di mana di Desa Banyuurip, Pangkahwetan, Cangaan, Janjangawan, Glatik dan desa ngemboh dengan kondisi masih tertinggal. Desa Pangkah kulon, Desa Sekapuk, Desa Gosari merupakan desa di Kecamatan Ujung Pangkah yang kondisi potensi desanya sangat baik, hal 
tersebut ditunjukkan dengan tidak ada satupun warna merah dari dimensi potensi desa yang ada.

Klasifikasi Desa Di Kecamatan Ujung Pangkah
Berdasarkan nilai Indeks Pembangunan Desa yang dicapai maka klasifikasi desa di Kecamatan UjungPangkah rata - rata masuk kategori Desa berkembang, yaitu: diantaranya Desa Pangkah

Tabel 3. Kalsisifikasi Desa di Kecamatan Ujung Pangkah

\begin{tabular}{|l|l|l|l|}
\hline \multicolumn{2}{|c|}{ NAMA DESA } & \multicolumn{1}{c|}{ KATAGORI DESA } \\
\cline { 2 - 4 } & TERTINGGAL & BERKEMBANG & MANDIRI \\
\hline PANGKAH KULON & & & \\
\hline KEBON AGUNG & & & \\
\hline SEKAPUK & & & \\
\hline BANYU URIP & & & \\
\hline BOLO & & & \\
\hline PANGKAH WETAN & & & \\
\hline GOSARI & & & \\
\hline CANGAAN & & & \\
\hline KARANGREJO & & & \\
\hline TANJANGAWAN & & & \\
\hline GLATIK & & & \\
\hline KETAPANGLOR & & \\
\hline NGEMBOH
\end{tabular}

Kulon, Desa Banyu urip, Desa Bolo, Desa Pangkah Wetan, Desa Gosari, Desa Cangaan, Desa Karangrejo, Desa Tanjang awan, Desa Glatik, Desa Ketapang Lor dan Desa Ngemboh. Desa Sekapuk menjadi satu-satunya Desa yang
Mandiri di Kecamatan Ujungpangkah. Sementara Desa Kebonagung menjadi satu-satunya Desa Tertinggal di Kecamatan Ujungpangkah. Variabel kualitas SDM merupakan satu satunya variabel

Tabel 4. Capaian Variabel Indeks Pembangunan Desa Kecamatan Panceng

\begin{tabular}{|c|c|c|c|c|c|c|c|}
\hline VARIABEL & PETUNG & SOROWUTI & SUMURBER & PANCENG & SIWALAN & BANYUTENGAH & CAMPUREJO \\
\hline PELAYANAN PENDIDIKAN & BERKEMBANG & BERKEMBANG & MANDIRI & MANDIRI & BERKEMBANG & MANDIRI & MANDIRI \\
\hline PELAYANAN KESEHATAN & BERKEMBANG & BERKEMBANG & MANDIRI & MANDIRI & BERKEMBANG & BERKEMBANG & BERKEMBANG \\
\hline INFRASTRUKTUR EKONOMI & BERKEMBANG & TERTINGGAL & BERKEMBANG & TERTINGGAL & BERKEMBANG & TERTINGGAL & BERKEMBANG \\
\hline INFRASTRUKTUR ENERGI & MANDIRI & MANDIRI & MANDIRI & MANDIRI & BERKEMBANG & MANDIRI & MANDIRI \\
\hline 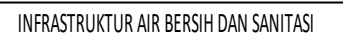 & BERKEMBANG & MANDIRI & MANDIRI & MANDIRI & MANDIRI & MANDIRI & MANDIRI \\
\hline INFRASTRUKTUR KOMUNIKASI DAN INFORMASI & TERTINGGAL & BERKEMBANG & TERTINGGAL & MANDIRI & TERTINGGAL & BERKEMBANG & BERKEMBANG \\
\hline SARANA TRANSPORTASI & MANDIRI & TERTINGGAL & TERTINGGAL & TERTINGGAL & TERTINGGAL & BERKEMBANG & MANDIRI \\
\hline AKSEBILITAS TRANSPORTASI & TERTINGGAL & MANDIRI & TERTINGGAL & BERKEMBANG & TERTINGGAL & BERKEMBANG & TERTINGGAL \\
\hline KESEHATAN MASYARAKAT & MANDIRI & $\begin{array}{l}\text { MANDIRI } \\
\end{array}$ & MANDIRI & $\begin{array}{l}\text { MANDIRI } \\
\end{array}$ & MANDIRI & $\begin{array}{l}\text { MANDIRI } \\
\end{array}$ & BERKEMBANG \\
\hline OLAH RAGA & TERTINGGAL & TERTINGGAL & TERTINGGAL & $\begin{array}{l}\text { MANDIRI } \\
\end{array}$ & TERTINGGAL & TERTINGGAL & $\begin{array}{l}\text { MANDIRI } \\
\end{array}$ \\
\hline KEMANDIRIAN & BERKEMBANG & BERKEMBANG & TERTINGGAL & TERTINGGAL & TERTINGGAL & TERTINGGAL & TERTINGGAL \\
\hline KUALITAS SDM & MANDIRI & MANDIRI & MANDIRI & MANDIRI & MANDIRI & MANDIRI & MANDIRI \\
\hline
\end{tabular}

yang hijau untuk tujuh desa di Kecamatan Panceng. Artinya bahwa di ketujuh desa tersebut kualitas sumber daya manusia yang dimiliki sudah sangat kompeten, baik kepala desa maupun sekretaris desanya sudah paham betul dengan tugas dan tanggungjawabnya, sedangkan pelayanan pendidikan, pelayanan kesehatan, infrastruktur energi, air bersih dan sanitasi.

\section{Capaian Dimensi Indeks Pembangunan Desa Kecamatan Panceng}

Berdasar Tabel 5. Desa Petung dan Desa Campurrejo merupakan desa yang memiliki dimensi cukup bagus, di mana fasilitas pelayanan dasar, kondisi infrastruktur, aksebilitas transportasi, pelayanan umum dan penyelenggaraan pemerintahannya tidak ada

Tabel 5. Capaian Dimensi Indeks Pembangunan Desa di Kecamatan Panceng

\begin{tabular}{|l|l|l|l|l|l|l|l|}
\hline \multicolumn{1}{|c|}{ DIMENSI } & \multicolumn{1}{|c|}{ PETUNG } & \multicolumn{1}{c|}{ SOROWUTI } & \multicolumn{1}{c|}{ SUMURBER } & \multicolumn{1}{c|}{ PANCENG } & \multicolumn{1}{c|}{ SIWALAN } & BANYUTENGAH & \multicolumn{1}{c|}{ CAMPUREJO } \\
\hline PELAYANAN DASAR & BERKEMBANG & BERKEMBANG & MANDIRI & MANDIRI & BERKEMBANG & MANDIRI & BERKEMBANG \\
\hline KONDISINFRASTRUKTUR & BERKEMBANG & BERKEMBANG & BERKEMBANG & MANDIRI & BERKEMBANG & BERKEMBANG & BERKEMBANG \\
\hline AKSEBILITAS/TRANSPORTASI & BERKEMBANG & BERKEMBANG & TERTINGGAL & TERTINGGAL & TERTINGGAL & BERKEMBANG & BERKEMBANG \\
\hline PELAYANAN UMUM & BERKEMBANG & TERTINGGAL & BERKEMBANG & MANDIRI & TERTINGGAL & TERTINGGAL & MANDIRI \\
\hline PENYELENGGARAAN PEMERINTAHAN & BERKEMBANG & MANDIRI & BERKEMBANG & BERKEMBANG & BERKEMBANG & BERKEMBANG & BERKEMBANG \\
\hline
\end{tabular}



yang menunjukkan kondisi tertinggal. Sementara, empat desa lainnya yaitu, Desa Sumurber, Desa Panceng, dan Desa Siwalan dimensi Aksebilitas transportasinya masih dalam kondisi tertinggal sedangkan Desa Sorowuti dan Desa Banyu Tengah serta Desa Siwalan fasilitas Pelayanan Umumnya kondisinya juga masih tertinggal. Desa Siwalan menjadi desa yang memiliki dua diminsi teringgal dibanding tiga desa lainnya yakni dimensi aksebilitas transportasi yang meliputi sarana transportasi dan aksebilitasnya serta dimensi pelayanan umum yang meliputi pelayanan Kesehatan masyarakat dan layanan olah raga.

\section{Klasifikasi Desa Di Kecamatan Panceng}

Secara umum tujuh desa di Kecamatan Panceng yang diteliti termasuk tipe Desa Berkembang.

Tabel 6. Klasifikasi Desa di Kecamatan Panceng

\begin{tabular}{|l|l|l|l|}
\hline \multicolumn{1}{|c|}{ NAMA DESA } & \multicolumn{3}{c|}{ KATAGORI DESA } \\
\cline { 2 - 4 } & TERTINGGAL & BERKEMBANG & MANDIRI \\
\hline PETUNG & & & \\
\hline SOROWUTI & & & \\
\hline SUMURBER & & & \\
\hline PANCENG & & & \\
\hline SIWALAN & & & \\
\hline BANYUTENGAH & & & \\
\hline CAMPUREJO & & & \\
\hline
\end{tabular}

Artinya bahwa ketujuh desa tersebut sudah mulai menggeliat menuju ke arah desa maju (on track). Beberapa pembangunan desa dan peningkatan layanan mulai dibenahi dan ditingkatkan untuk menuju desa mandiri.

\section{KESIMPULAN}

1. Kategori Desa Berkembang di Kecamatan Ujung Pangkah adalah Desa Pangkah Kulon, Desa Banyu urip, Desa Bolo, Desa Pangkah Wetan, Desa Gosari, Desa Cangaan, Desa Karangrejo, Desa Tanjang awan, Desa Glatik, Desa Ketapang Lor dan Desa Ngemboh. Sedangkan Desa Sekapuk menjadi satusatunya Desa yang Mandiri di Kecamatan Ujungpangkah. Sementara Desa Kebonagung menjadi satu-satunya Desa Tertinggal di Kecamatan Ujungpangkah.

2. Seluruh Desa yang menjadi lokasi kajian di Kecamatan Panceng yakni Desa Panceng, Desa Sorowuti, Desa Sumurber, Desa Siwalan, Desa Petung, Desa Banyutengah, dan Desa Campurejo masuk kategori Desa Berkembang.

3. Rata-rata variable yang kondisinya tertinggal di hampir seluruh desa di Kecamatan Ujung Pangkah adalah variable Sarana Olah Raga dan Sarana Transportasi. Sedaangkan variable yang sangat baik rata rata di seluruh desa di Kecamatan Ujung Pangkah adalah infrastruktur energi, kesehatan masyarakat dan kualitas SDM nya.

4. Di Kecamatan Panceng Variabel Olah raga dan Kemandirian rata-rata kondisinya di tujuh desa kajian masih kurang baik (tertinggal), sedangkan variable pelayanan Pendidikan, pelayanan Kesehatan, infrastruktur energy, kualitas SDM, Kesehatan masyarakat dan infrastruktur air bersih dan sanitasi sudah cukup baik, khususnya kualitas SDM semua desa sudah mandiri.

\section{SARAN}

1. Perlu ada strategi yang tepat untuk meningkatkan pembangunan di desa Kebonagung dengan menggali potensi desa yang ada terutama dalam hal pelayanan Kesehatan, infrastruktur ekonomi, infrastruktur air bersih dan sanitasi serta kemandirian desa.

2. Perlu kiranya desa-desa di Kecamatan Ujung Pangkah untuk menyediakan fasilitas olah raga yang memadai dan memperbaiki sarana transportasi.

3. Secara Umum di Ketujuh desa Kajian di Kecamatan Panceng hendaknya mulai lebih mempersiapkan untuk menuju otonomi desa (menjadi desa mandiri).

\section{DAFTAR PUSTAKA}

Badan Perencanaan Pembangunan Nasional (Bappenas). (2001). Indeks Pembangunan Daerah (Regional Development Index). Draft/Rancangan dalam Bentuk Ringkasan. Jakarta: Bappenas 
Badan Pusat Statistik (BPS) Kabupaten Tuban (2015) Kecamatan Dalam Angka di Kabupaten Tuban 2014

Hidayati, Roziana Ainul, Sholichah (2010), Model Pengentasan Kemiskinan Nelayan di Pesisir pantai Utara jawa Timur I

Hidayati, Roziana Ainul, (2013), Pola Kemiskinan Nelayan di Kabupaten Gresik (2013)

Hidayati, Roziana Ainul, (2014), Analisis Strategi Program Pengentasan Kemiskinan berdasar Millenium Development Goals di Kabupaten Gresik.

Hidayati, Roziana Ainul, (2015) Analisis Pengukuran Pencapaian Penanggulangan Kemiskinan dan Kelaparan di Kabupaten Tuban Menggunakan Poverty and Hunger Index

Hidayati, Roziana Ainul, (2016) Analisis Progress Pencapaian MDGs di Provinsi Jawa Timur

http://103.142.210.111:83/files/122143Laporan\% 20Survei\%20Kepuasan\%20Masyarakat $\% 2$ 0Tahun\%202017.pdf

Peraturan Pemerintah Nomor 43 Tahun 2014 tentang Peraturan Pelaksanaan UndangUndang Nomor 6 Tahun 2014 tetang Desa (Lembaran Negara Republik Indonesai Tahun 2014 Nomor 123, Tambahan Lembaran Negara Republik Indonesai Nomor 5539).

Permendagri No. 66 Tahun 2007 Tentang Perencanaan Pembangunan Desa.

Satria, Ase. 2015, Inilah Beberapa Definisi Pembangunan Desa Menurut Para Ahli, http://www.materibelajar.id/2015/12/inilah -beberapa-definisi-pembangunan_28.html

Undang-Undang Nomor 6 Tahun 2014 tetang

Desa (Lembaran Negara Republik Indonesai

Tahun 2014 Nomor 7, Tambahan Lembaran Negara Republik Indonesai Nomor 5495)

www.bappenas.go.id/index.php/download file/vi ew/17767/8888/

www.sapa.or.id/lp/7748-sistem-informasi-desa$\underline{000006}$ 